は，複眼色素が 網膜色素紐胞の 最下部まで下降してお

り，暗期では，円錐晶体の上部に色素が上昇し，明らか に glow spot が観察された。全暗区(D)では，色菜が 下゙降して暗適心の状態であり，全明区(L)では，色素が 上昇して明適心の状態であった。

3 つの明暗条件区における活動個体数を第 3 図に示し

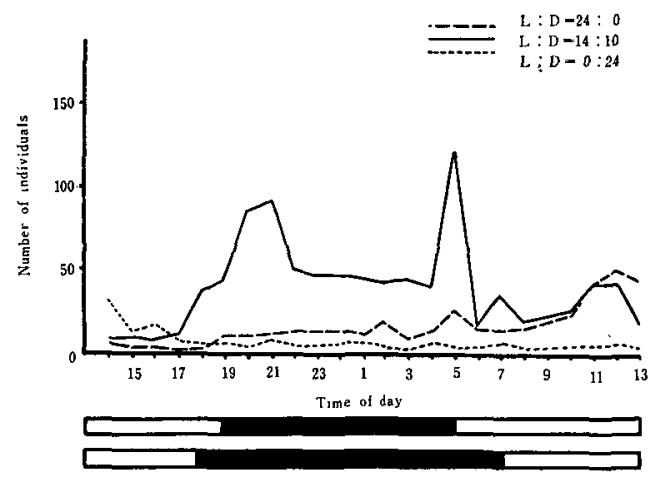

Fig. 3. Diurnal variation of the behavior in 3 different conditions.
た。すなわち，自然日長区では，明から暗への転換後に 活動個体数が増加し，その後，減少するが，明期よりは 活発な状態が続く。また, 暗から明へ転換直後, 再び活 動個体数が増加し, その後, 減少して明期中は不活発で あった。また，全明区では，24時間を通じて，全暗区よ りいくらか活発な傾向があり, 全暗区では不活発であっ た。なお, 全明区の活性がいくらか高いのは, 観察箱内 の恒温装置が作動して $1^{\circ} \mathrm{C} \sim 2{ }^{\circ} \mathrm{C}$ 上昇することによって 生じるととを確珰した。

以上のととから，自然日長区では，複眼が明適応から 暗適応に変る時と, 暗適応から明適応に変る時に, 活動 個体数が多く，活動時期と色素の移動期とが一致してい るととが判る。また，完全に暗適応した蛾は，光の刺激 に敏感であり，明適応している時は反応しにくいことを 併せると，自然の光周期があってはじめて暗期の活動が 誘起されるのではないかと推察される。さらに, 幼虫期 から蛹期までに受けた光䧓期による内在的リズムが成虫 にあるのではないかと考えたが，今回の奏験では確䜑で きなかった。

\title{
イネ科飼料作物ソルゴーを加害するヒエノアブラムシの生態
}

（第2 報）産 卵䊒 虫の産 卵生態

\author{
瀬局口俩（麇児島県農業試騟場大隅支場）
}

\section{Ecology of Longiunguis sacchari (ZEHENTNER) (Aphididae) infesting sorghums.} II. Observations on the oviposition

Osamu Seтokuchi (Osumi Branch, Kagoshima Agricultural Experiment Station)

The sexuals of Longiunguis sacchari (ZEHENTNER) on sorghums appear in autumn, and the oviparous females deposit the overwintering eggs on the host plants in a field. In this paper, oviposition of the oviparous female was reported. The average ovipositing period was 7 days, and the average number of eggs per female was 5.7, being deposited within a few days for the most part after the beginning of oviposition. The oviparous females were reared on the mature leaves of sorghum (Sörghum vulgare) in the laboratory (mean temperature $17.7^{\circ} \mathrm{C}$ ) and began to deposit within 2 days after mating. Eggs were usually deposited on the underside of leaf blade or leaf sheaths in the lower parts of plants in the field.

ソルゴーに寄生するヒェノアブラムシ Longiunguis sacchari(ZEHENTNER) の両性世代虫の出現と産莭につ いて，わが国では MORITSU et al. (1971) の報告があ

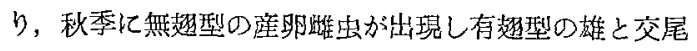
後同一寄主植物上(ソルゴー) に産卵するというととが 明らかになった。しかしソルゴーは一年生牧草であり， これらの卵の翌春の発生源としての役割は不明である。 今後, 越冬を中心に本種の広範な生活史を明らかにする 必要があるが，こてではソルゴーでみられた卵態越冬の
実態を知るために，産畉雌虫の蓙卵期間，産卵数わよび 野外のソルゴー上の産卵部位の調查結果を報告する。報 告に際し本研究の遂行に種々御教示いただいている山口 大学森津孫四郋教授に䫍謝の意を表する。

\section{材料および方法}

\section{1. 産卵期間・産卵数（室内実験）}

室温下にて等代飼育中出現した産畉崔虫および雄を估 試虫として，管びん $(1.5 \times 6 \mathrm{~cm})$ に雌雄 1 組ずつ入れ 
た。睢は成虫になって1日以内のものを供試したが雄の 日令恃考慮しなかった。11月14日から12月25日（1973） まで室温下 (平均 $17.7^{\circ} \mathrm{C}$ ) で飼育し, 毎日産卵数を調查 した。食草としてはビニールハウス内に鉢植えしたソル ゴーSorghum vulgare RERS.（ニューソルゴー）の成 葉を与えてほぼ一日おきにとりか元た。

\section{2. 産. 卵 部 位 (野外調査)}

ソルゴーが枯死してますない12月18日（1971）野外の ソルゴー50本について草高を 3 等分し, 上, 中, 下位部 にわけそれれぞれの部位の茎葉に付着していた卵数を調 査した。

\section{結果および考察}

室内での観察汇よると, 産畍雌虫は雄と交尾後遅くと も2 日目には産卵を開始した。交尾は雄が㬨の上にのり 雄雌同方向をむいて行ない，初交尾には約10１2分間を 要した。なお甽は長径約 $0.63 \mathrm{~mm}$, 短径約 $0.32 \mathrm{~mm}$ の棈円形 をしており，産䀢直後は黄橙色をしていたが，約10日後

Table 1. Ovipositing period and number of eggs produced at the mean room temperature of $17.7^{\circ} \mathrm{C}$

\begin{tabular}{c|c|c|c}
\hline $\begin{array}{c}\text { No. of } \\
\text { females } \\
\text { tested }\end{array}$ & $\begin{array}{c}\text { Ovipositing } \\
\text { period } \\
\text { (days) }\end{array}$ & $\begin{array}{c}\text { Total no. of } \\
\text { eggs } \\
\text { produced }\end{array}$ & $\begin{array}{c}\text { No. of eggs } \\
\text { produced } \\
\text { per day }\end{array}$ \\
\hline 30 & $1 \sim 13$ & $2 \sim 9$ & $0.4 \sim 3.0$ \\
(Avg.) & $(7.0)$ & $(5.7)$ & $(0.8)$ \\
\hline
\end{tabular}

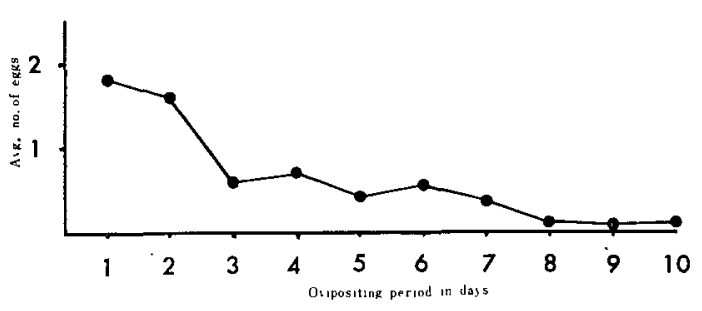

Fig. 1. Ovipositing period and number of eggs produced per female in a day.
にはつやのある黒色となった。

\section{1. 産卵期間・産卵数}

産畉期間, 産卵数の調查結果わよび毎日の産卵状況は それぞれ第1表，第1図に示した。これらの結果から， 産畉期間は平均 7 日間と短く, 産卵開始後 2 日間で産卵 数の多くを産下してしまう傾向がみられた。森津(1959) は，アブラムシの産莭はおよそ10日以内に終了するもの が多いと報告したが，本種も10日以上産畉する個体はほ とんどみられなかっだ。また産莭数は 2 〜個, 平均 5.7 個で宗林 (1958)，高岡（1960）がモモアカアブラムシ Myzus persicae (SULZER) で観察した産贁 4 ～10個 と似かよった値となった。

\section{2. 産 卵 部 位}

野外のソルゴー50本を調查した結果, 合計約 1.500 個 の卵が発見された。発見された卵の産卵部位别卵数は第 2 表に示したが，前述のように1踓当り平均 5.7 個産卵 したとすれば, ソルゴー 1 本当り $5 \sim 6$ 頭の産卵雌虫が 出現したととになろう。るっとも多く卵のみられたのは 葉身の襄側で全体の70\%近くがここで発芫された。次に は葉鞘の内側に多く, 䔄や葉耳部ではほとんど発見され なかった。また草高でみると下位部に多く約 $65 \%$ を占め た。しかしソルゴーは冬季に完全に估死するため, てれ らの産卵部位の選択は翌春, 卵が残存して幹母が出現し ても，その寄生部位や㩒食にまったく関連をもたず，森 津（1959）が他のアブラムシ類について指摘したと同じ ように単に卵が付着し，残存しやすい粗雑な場所を遙ん で産㽗したと考えられる。室内飼育に用いた管びんのコ ルク栓に産畉する個体がみられたととも，てのととを裏 づけるものであろう。

\section{引用 文 献}

1) 森津係四郎(1959) 山口大農学学術報告 10：1219 21224. 2) Moritsu, M. et al. (1971) Bull. Fac. Agr. Yamaguchi Univ. 22: 209 214.

3）宗林正人 (1958) 関西病虫研会報 1: 54 60.

4）高岡市郎(1960) 案野たばて試報告 48: 1 95.

Table 2. Number of eggs laid on various parts of sorghums in the field

\begin{tabular}{|c|c|c|c|c|c|c|c|}
\hline \multirow{2}{*}{ Height } & \multicolumn{2}{|c|}{ Leaf blade } & \multicolumn{2}{|c|}{ Leaf sheath } & \multirow{2}{*}{ Auricle } & \multirow{2}{*}{ Stem } & \multirow{2}{*}{ Total } \\
\hline & Upper & Under & Outside & Inside & & & \\
\hline $\begin{array}{l}\text { Upper } \\
\text { part }\end{array}$ & 13 & 65 & 7 & 115 & 0 & 0 & $\begin{array}{c}200 \\
(13.3)\end{array}$ \\
\hline $\begin{array}{l}\text { Middle } \\
\text { part }\end{array}$ & 20 & 273 & 0 & 38 & 0 & 0 & $\begin{array}{c}331 \\
(22.1)\end{array}$ \\
\hline $\begin{array}{c}\text { Lower } \\
\text { part }\end{array}$ & 62 & 678 & 45 & 182 & 1 & 0 & $\begin{array}{c}968 \\
(64.6)\end{array}$ \\
\hline Total & $\begin{array}{c}95 \\
(6.3)\end{array}$ & $\begin{array}{c}1016 \\
(67.8)\end{array}$ & $\begin{array}{c}52 \\
(3.5)\end{array}$ & $\begin{array}{c}335 \\
(22.3)\end{array}$ & $\left(0 . \frac{1}{1}\right)$ & 0 & $\begin{array}{l}1499 \\
(100)\end{array}$ \\
\hline
\end{tabular}


筑後地方におけるハスモンヨトゥ雄成虫の発生実態

宮原義雄（九州農業陚験場）

ハスモンヨトウ成虫の調查手段として，処女惟トラッ プは，ブラックライトより極めて高い誘致效率を有する

(宮原，1973)。かつ，トラップ間隔が400m程度雁れて いても，その誘殺消長には，特に高密度時に，高い類似 性がみられる(九州農試，1974）。従来，乙の蛾の調查 には，白熱灯，高圧水銀灯，ブラックライトなどが用い られてきたが，処女淮トラップの上記のような特徵から， この方法を用いて筑後地方における雄成虫の発生実態を 明らかにしようと考元た。また，トラップ間隔がさらに 隔たった地点間における誘殺消長の類似性についても， あわせて比較検討しようとした。

方法

調查地点は第 1 図のように，福岡県の八女市，筑後市， 大川市を結ぶ県道沿いにありいずれの地点も柰道の南 側であった。各地点は九州農試（筑後市）内に設けた卜 ラップAを中心として，八女方向および大川方向の両 方向に，ほぼ機械的に 1，2，4，8 k四に設けた。別に， 大川方向の $400 \mathrm{~m}$ 地点についてもトラップ (D) を設け た。処女雌トラップによる調查方法は前報(宮原，1973) と同様であった。すなわち，地面から $1.3 \mathrm{~m}$ の高さにプ ラスチック製のトラップを置き，毎日羽化翌日の倠10頭 をうェロモン源とした。調查期間は 8 月10日から 8 月30 日までで，乙の間，毎日全トラップの誘殺数を記録し た。

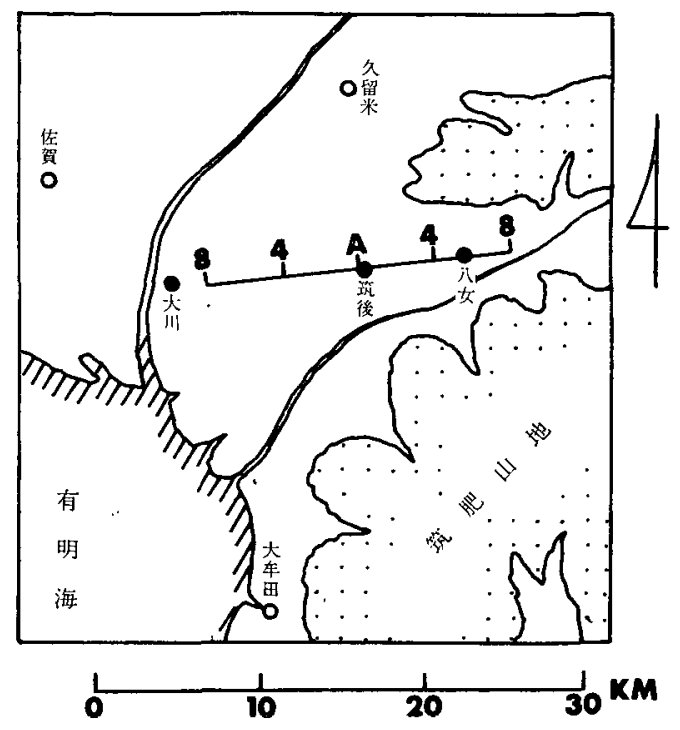

第 1 図調查地带の概要図

結果および考察

九州農試内のトラップAにおける5月加ら11月までの 㛬殺消長は第 2 図に示される。このトラップには，5月 以前についても誘殺されたが図示されていない。第2図 の斜線の期閶は，各地点で同時に調查を実施した期間を 示し，乙の図の誘殺消長に上れば第 4 回成虫の発蛾初期

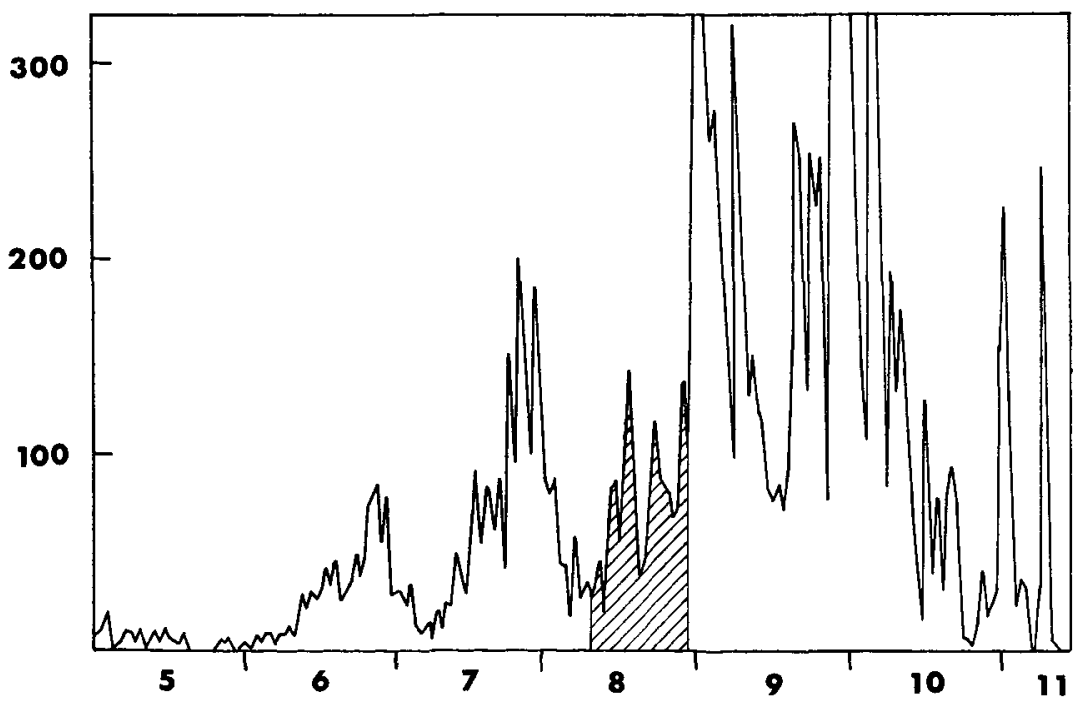

第 2 図九州農試（A）における日別誘殺消長 


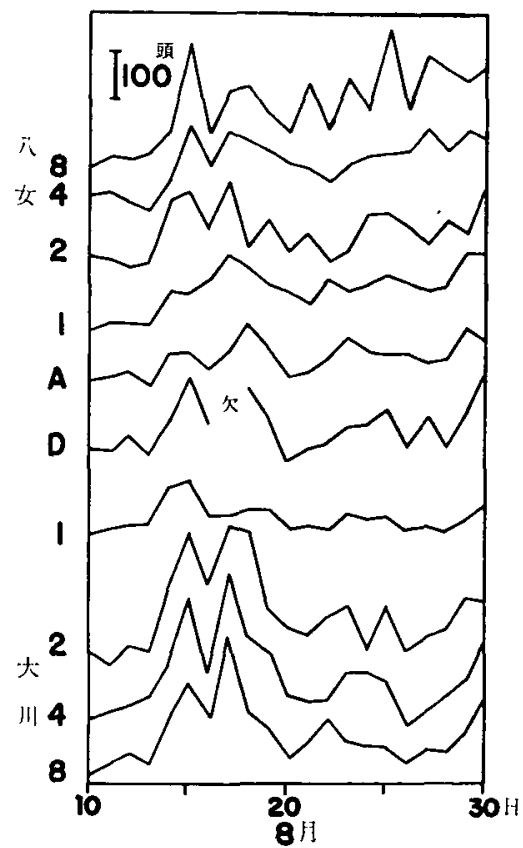

第3図各地点の日別誘殺消長

（注）各地点いずれも誘殺数 0 の位圆は示さ れていない。相対的な傾向を示す。
から、ピーク時にかかる直前までの期間と推定される。 各地点の息別誘殺消脣は第 3 図のようである。各地点 の結果を概括すると，8月15～17日頃に小さなピークが あり，いっだん誘殺数は減少し，月末にむかって再び徐々 に増加の傾向をたどり，このあと第2図から明らかなよ うに急激に増加したものと思われる。各地点のうち, 大 川の $2,4,8 \mathrm{~km}$ 地点の誘殺消長には, 著しい類似性がみ られる。これらの3 地点は，いずれも有明海に近い筑後 平野のクリーク地帯に位苜し，第 4 図に示されるように， トラップ周䢌の状洗も非常に良く似ていた。

2 地点間の日別誘殺数について相関系数を求めた結果 は第 1 表のようである。上記，大川方向の 3 地点䦧の相 関係数は，それぞれ，0.886，0.865，0.916 と他の地点 間におけるそれより明らかに大きかった。一可，八女側 の2, 4, $8 \mathrm{~km}$ 間では, 大川側のような類似性はみられ なかった。特に， $4,8 \mathrm{~km}$ 地点のトラップ周辺の状沅は 非常に良く似ていたが (第 4 図)，誘殺数の日変動は著 しく傾向が異なった。各地点の中心に位置するトラップ Aの結果は，第 3 図および第 1 表の結果加ら判断すると， 大川側の地点よりむしろ八女側の地点を代表しているす のと思われる。これら10地点のなかで，大川1 kmのトラ ップは,どのトラップとも傾向が異なった。これは後で

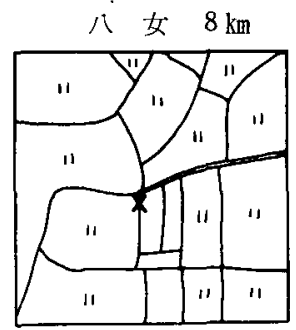

A（九州農試）

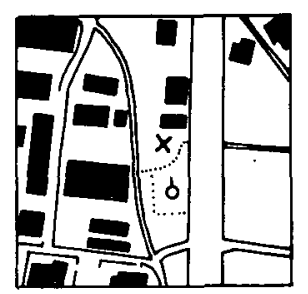

大 川 4

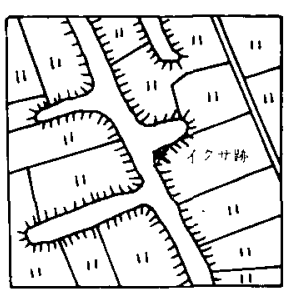

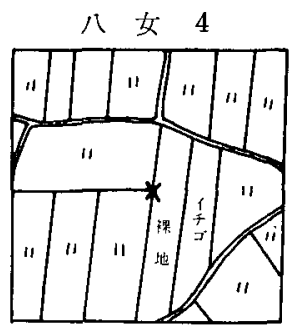

$\mathrm{D}$
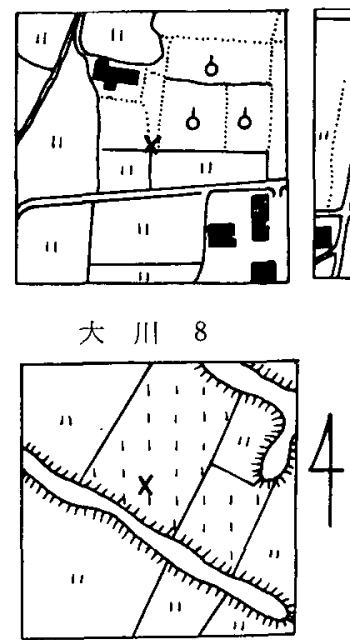

八女 2

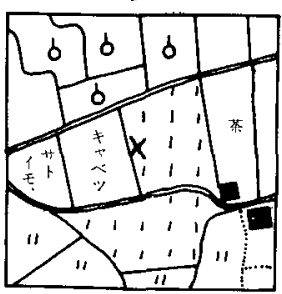

大 III 1
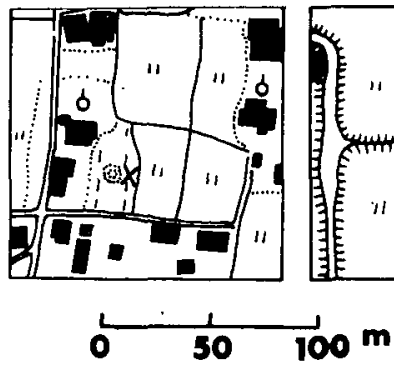

11水确

$1,1 /$ 休耕四

d 果 啮

メトラップ

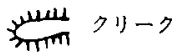

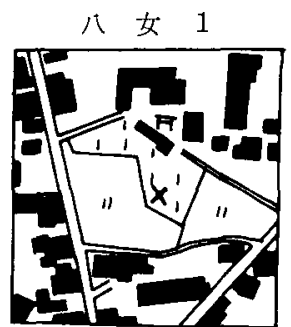

大 $\| 2$

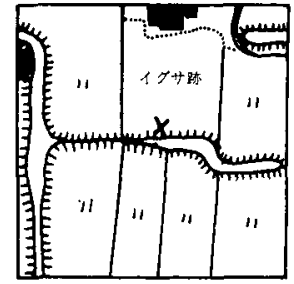

C建 物

њ is

第 4 図卜ラップ周䢌の状況 
第 1 表各調查地点間における誘殺数の相関係数

\begin{tabular}{|c|c|c|c|c|c|c|c|c|c|c|c|c|}
\hline \multirow{2}{*}{ 調 } & \multirow{2}{*}{ 查＼cjkstart地 } & \multirow{2}{*}{ 点 } & \multicolumn{2}{|c|}{ 八 } & \multicolumn{2}{|c|}{ 女 } & \multirow{2}{*}{ A } & \multicolumn{2}{|c|}{ 大 } & \multirow[b]{2}{*}{2} & \multicolumn{2}{|c|}{111} \\
\hline & & & 8 & 4 & 2 & 1 & & D & 1 & & 4 & 8 \\
\hline \multirow{2}{*}{ 八 } & & $8 \mathrm{~km}$ & & & & & & & & & & \\
\hline & & 4 & 0.810 & & & & & & & & & \\
\hline \multirow[t]{2}{*}{ 女 } & & 2 & 0.569 & 0.646 & & & & & & & & \\
\hline & & 1 & 0.609 & 0.778 & 0.618 & & & & & & & \\
\hline A & & 0 & 0.600 & 0.698 & 0.418 & 0.785 & & & & & & \\
\hline \multirow[t]{2}{*}{$\mathrm{D}$} & & 0.4 & 0.623 & 0.671 & 0.735 & 0.601 & 0.688 & & & & & \\
\hline & & 1 & 0.369 & 0.384 & 0.673 & 0.317 & 0.465 & 0.733 & & & & \\
\hline \multirow{3}{*}{$\begin{array}{l}\text { 大 } \\
M 11\end{array}$} & & 2 & 0.457 & 0.593 & 0.579 & 0.611 & 0.562 & 0.749 & 0.687 & & & \\
\hline & & 4 & 0.431 & 0.579 & 0.731 & 0.556 & 0.530 & 0.827 & 0.721 & 0.886 & & \\
\hline & & 8 & 0. 384 & 0.558 & 0.712 & 0.648 & 0.496 & 0.805 & 0.628 & 0.865 & 0.916 & \\
\hline
\end{tabular}

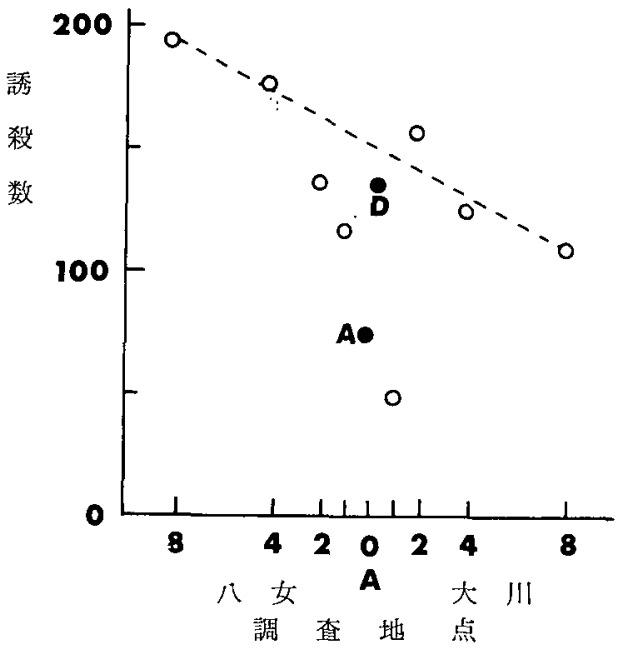

第 5 図各地点の平均誘殺 数

述べるように，トラップの設置場所の条件が大きく影響 しているように思われる。2地点間の相関係数は，地点 間の距離が摘たるにしたがって，その值は小さくなるて とが期待されるが，事実，八奴大昉向，逆に大川 から八女方向のいずれの場合も小さくなった。

各地点の誘殺数の平均值（日あたり誘殺数）を距離ご とにプロットすると第 5 図のようになる。この図から， 誘殺数は八女 $8 \mathrm{~km}$ 地点から大川 $8 \mathrm{~km}$ 地点们向って，ほぼ 直線的に減少している。山間部に近い八女から，海岸部 の大川にかけてのてのような謹殺数の傾斜については, ハスモンヨトウの寄主植物である野菜，花などの作付面 積が関連しているのではない加と考无られるが，乙れを 裏付ける資料を持たない。いずれにしてる，八スモンヨ トウは，稲作地带である筑後地方においても，普遍的に 分布しているととを示している。
各地点のうち, 八女 $1 \mathrm{~km}, \mathrm{~A}$, 大川 $1 \mathrm{~km} の 3$ 地点, 特 に後者の 2 地点は，著しく誘殺数が少なかった。てれは 第 4 図に示されるトラップ周辺の状況から明らかなよう に，乙れらの地点はトラップに近接する建物，やふ，果 樹園が，トラップの機能を発揮するうえで障害になった ものと思われる。トラップAはこのような意跦から，調 査地点として好ましい地点ではない。大川 $1 \mathrm{~km}$ 地点は, 先に述べたように誘殺消死が著しく他と異なったが，誘 殺数も全トラップのなかでもっとも少なかった。てれは トラップの西側に近接してやぶのあうたととにあわせて， トラップを休耕田に設けざるを得なかったととから図の 西南のすみに片寄ったととも関係しているように思われ る。特に，八女 $1 \mathrm{~km}$ 地点と比較した場合，その感が深い。

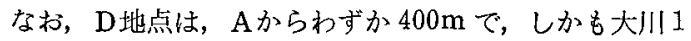
$\mathrm{km}$ 地点との間に位置したが, 設置場所の条件から誘殺数 にはほとんど影響はみられない。これらの結果から，処 女睢トラップの設置場所は, トラップ周辺に建物, 樹木 などの障害物のない条件が必要と思われる。

\section{摘}

要

筑後地方における八スモンヨトウ雄成虫の発生実態を， 処女雌トラップを用いて調べた。その結果，誘殺数は， 山間部側の八女から海岸側の大川にかけて，直線的な减 少がみられた。稲作地带である筑後地方においても，こ の蛾は普遍的に分布するものと思われる。調查地点間に おける誘殺消長の類似性や，誘殺数に影響をおよぼす卜 ラップの設置場所の条件についても述べた。

\section{引用 文 献}

1) 九州農業試験場虫害第 1 研究室 (1974) 害虫の総 合的防除法汇関する研究成績 (とう写)：43〜 44。 宮原義雄（1973） 九病虫研会報 19：101～103. 


\section{鹿児島県におけるキャベ・ッの病害虫}

第3 報モン シ 口 チ

堀切正俊(鹿坚島県農業試験場)

鹿児島県におけるモンシロチョウ幼虫の死亡要内を知 るため1972年から調偍を実施しているが，今回は第 2 世 代幼虫（春期多発期）の生存率について報告する。

\section{方}

法

農業試験場病虫部畑纪網の目の異る木枠 $(1.1 \times 1.2 \times$ $2.4 \mathrm{~m}$ ，約 $2.9 \mathrm{~m}^{2}$ ) を設置し，卵を接種したポット植えの キャベツを10株，予備として10株計20株を植え込み，そ の後の生存状況を調査した。区の構成は，全ての天敵を 遮断するために寒冷紗網(21メッシュ)のA区，鳥，蜂の 効果をみるためサラン網 (14メッシュ)のB区，鳥を除 去するため亀甲金網のC区，全ての天敵から攻撃をうけ る無処理のD区を設けた。卵の接種は，ポット植えのキ ヤべツを寒冷紗網化の中に入れ，雌雄成虫を 100 頭内外 放飼して 2 日間産卵させ，その後 1 株每に畉数を調查し， 1 区430粒内外（1972年は400粒）になるようにした。な お，試験開始前に A, B 両区に DDVP 乳昘の 1,000 倍 液を充分散布し，調查中もクモなどみとめた場合はその 都度取り除いた。

区制は1区制で，1972年は5月14日〜6月19日，1973 年は 5 月 14 日〜 6 月 22 日に実施した。

\section{結 果 と 考 察}

調查方法の関係から，ここでは令期別個体数の推移で なく接種㽗に対する生存率宗した(第 1 図)。

生存率があとになって上舁しているのは, 前回の調査 時見落し個体があったためであるが，両年を通じ即期か ら幼虫初期にかけての死亡がもっとも大きく，幼虫末期 から蝻期にかけてがてれについだ。区間ではA区の生存 率がもっとも高く，ついでB区，C区の順で，無処理区 のC区がもっとも低かった。との㑯向は両年度とも一致 しているが，1972年は $\mathrm{A} \geq \mathrm{B}>\mathrm{C} \geq \mathrm{D}$ 区，1973年は $\mathrm{A}>$ ， $\mathrm{B}>\mathrm{C} \fallingdotseq \mathrm{D}$ 区と，1972年は1973年に比べ A区で1/3，B区 で $1 / 2$ 内外に生存率の低下をみた。てれはあとで示す蛹寄 生のアオムシコバチによるものである。

つぎ種々の要因で死亡した個体を接種卵に対する比 率で示したのが第1表である。

無処理のD区では，卵から成虫になるまで9.7〜99.8 \%が死亡したととになり，C区においても99〜99.8\%と 高率で，宮下ら（1958）の報告，老令幼虫の移動など考 慮するとやや過大評価の嫝らいもあるが，いずれにして も非常に高い死亡事といえる。

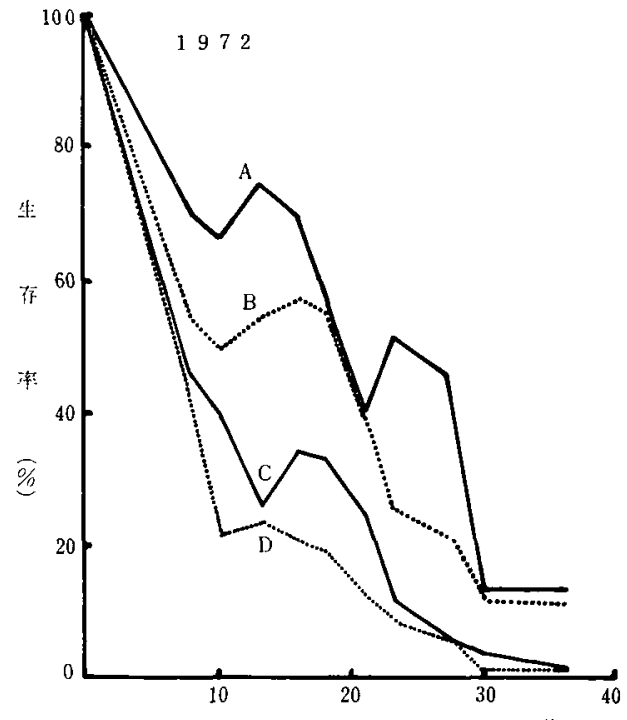

経洫

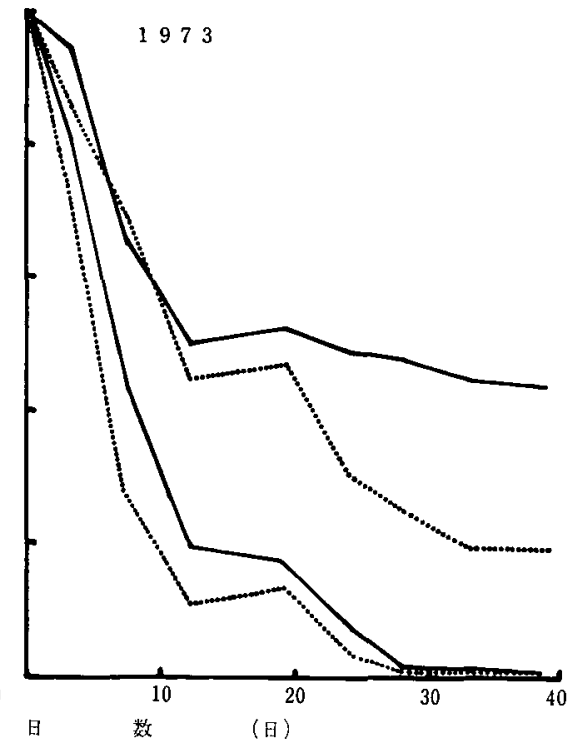

(日)

第 1 図モンシロ

（注） $\mathrm{A} ：$ 寒レイシャ網区， B：サラン網区， C ：庽甲金網区， D：無処理区. 
第 1 表 モンシロチョウ第 2 世代幼虫の死亡要因

\begin{tabular}{|c|c|c|c|c|c|}
\hline $\begin{array}{l}\text { 調查 } \\
\text { 時期 }\end{array}$ & 項 & $\begin{array}{c}\mathrm{A} 区 \\
\text { 寒冷紗 } \\
(\%)\end{array}$ & $\begin{array}{l}\text { B区 } \\
\text { サラ } \\
(\%)\end{array}$ & 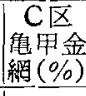 & $\begin{array}{c}\mathrm{D} 区 \\
\text { 無处理 } \\
(\%)\end{array}$ \\
\hline \multirow{2}{*}{1972} & 病 死 虫 & 0 & 0 & 0 & 0 \\
\hline & $\begin{array}{l}\text { アムシサムライ } \\
コ マ \neg ハ ゙ チ\end{array}$ & 8.3 & 36.3 & 37.0 & 2.5 \\
\hline \multirow{3}{*}{$\begin{array}{c}\text { ? } \\
6.19\end{array}$} & 蛹化までの死亡 & 46.7 & 77.4 & 97.7 & 99.7 \\
\hline & アオムシコバチ & 38.5 & 10.8 & 0.5 & 0 \\
\hline & 羽化までの死亡 & 86.7 & 89.2 & 99.0 & 99.7 \\
\hline \multirow[b]{2}{*}{1973} & 病死虫 & 0.2 & 1.7 & 2.1 & 3.5 \\
\hline & $\begin{array}{l}\text { アムシサムライ } \\
コ マ \text { マ }\end{array}$ & 3.0 & 24.6 & 13.5 & 8.6 \\
\hline \multirow{2}{*}{$\begin{array}{c}5.14 \\
?\end{array}$} & 蛹化までの死亡 & 55.1 & 75.7 & 99.3 & 99.5 \\
\hline & アオムシコバチ & 0.9 & 1.2 & 0 & 0 \\
\hline 6.22 & 羽化までの死亡 & 56.2 & 80.6 & 99.8 & 99.8 \\
\hline
\end{tabular}

これに対しA区の死亡率は56〜86\%，B区では80〜89 \%と歩留りが良かった。年次変動在生じたのはアオムシ コバチがその主因と考元られる。一方，アオムシコマユ バチの寄生は，1972 年が30\%（B区一A区），1973年が 20\%（同上）内外，アシナガバチ類(フタモンアシナ代 バチが主）による捕食は1972年が20\%（蛹化までの死亡 率 $\mathrm{C}$ 区一 $\mathrm{B}$ 区)，1973 年が $24 \%$ （间上）内外之推定され
ることから，その年次変動はアオムシコバチに比べ小さ く，幼虫の生育後期における強力な死亡要因を占めてい るものと考えられる。

なお春期多発時のアオムシサムライコマユバチの寄生 率が，南九州では90\%以上であるという松沢（1958）の 報告と異なるのは，調查方法の差異（5令幼虫のみを対 象）によるものと考えられる。鳥による捕食効果は明ら かでなかった。

卵期から幻虫初期にかけての死亡要因については明ら かにし得なかったが，今後検討したい。

\section{摘要}

1972，1973年，モンシロチョウ第 2 世代幼虫の生存率 について調查した。

両年とも眼期と幼虫初期の死亡がもっとも大きく，幼 虫末期加蛹期にかけててれについだ。初期の死亡要因 は不明であるが，奻虫末期にはアオムシサムライコマユ バチ，アシナガバチによるものが大きく，年によっては アオムシコバチ（蛹寄生）の影響る大きいと考元られる。

\section{引用文献}

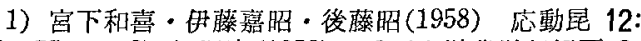
$50 \sim 55.22)$ 松沢寛(1958) 香川大学農学部紀要 3 : $1 \sim 125$.

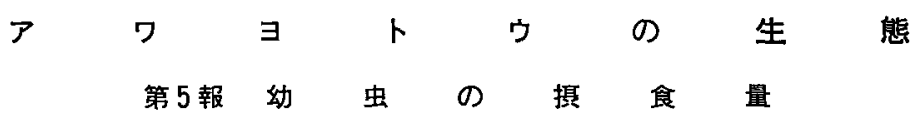

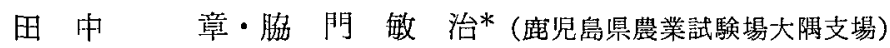

アワヨトウは乫発的な大発生をおこすと同時に，南九 州では活とんど每年 5 月から6月までの第 1 世代が飼料 作物ほ場でかなり高い密度で発生している（田中・大内， 1972)。本種による加害部位は 飼料として重要な部分で ある葉への直接害であり，乙の虫の椇食による被喠は大 きいものと思われる。しかし，ての上うな飼料作物を対 象としての害虫防除を考兵る時，農薬の使用を少なくす る意味からも適確な要防除密度や時期を知るととが必要 であり（桐谷・中筋，1971），そのためにはまず幼虫の 摃食量を知ることは重要であろう。

アワヨトウ幼虫の掑食量について, 㿂（1958）はイヌ ムギで飼育し，飼育密度々揁食量の関係を調べままた児 玉ら（1963）はイネで摂食量者面積で表わし，防除の必 要な幼虫密度を推定している。

一方, 森下 (1973) は経済生命表 (Bioeconomic life

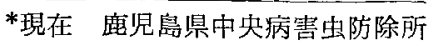

table）を提唱し，生命表の中に摂食量，同化量，呼吸量 などの生物経済学的な内容を同時に示すととが，個体群 の動態解析に重要な意義を持つだろうと遮べている。

そてで筆者らは, 飼料作物ほ場での本種の発生密度々 被害の関係を知る一方法として, 飼料作物のトールフェ スクとソルゴーを与えた場合の提食量を調查し，またて れをもとに今後要防除密度を知るための被害率を推定し たので報告する。

報告に先だち，飼料作物についていろいるとご教示下 さった，当場牧草育種研究室の宝満正治室長, 報文のご 校閲を賜わった永冨昭先生に深謝致します。

\section{材料および方法}

供試虫はトウモロコシ飼有で得られた成虫から採畉 した同一卵塊のふ化幼虫に 食草としてトールフェスク (Festuca arundinacea 品種, ケンタッキー31), ソル 